\title{
Study of chronology of closure of cranial sutures in females
}

\author{
Yashwant Kumar Singh ${ }^{1}$, Rajneesh Kumar Pandey ${ }^{2, *}$, S. Harish ${ }^{3}$, Girish Chandra YP ${ }^{4}$ \\ ${ }^{1,2}$ Assistant Professor, ${ }^{3,4}$ Professor, Dept. of Forensic Medicine, Shyam Shah Medical College, Rewa, Madhya Pradesh, India
}

*Corresponding Author:

Email: rajneesh.nightwalker@gmail.com

\begin{abstract}
Various features in an unknown body aid in establishing identity of the deceased, which is a challenging task for forensic experts at autopsy, of which age estimation is an integral part. Various methods are used to estimate age at death, such as, in the subadult group; appearance and fusion of primary and secondary ossification centers, epiphyseal union, and tooth eruption, which have long been studied and proved useful. In adults; pubic symphysis, auricular surface of hip bone, sternal ends of rib, cranial suture closure, secondary dental changes and histological methods have been mentioned in various studies.

Estimation of age becomes difficult as the age advances, particularly after the age of 20-25 years. One such index in age estimation beyond 25 years is the closure of the cranial sutures both ectocranially and endocranially. Hence this study is undertaken to find out the age of cranial suture closure in females and its reliability in estimating age.
\end{abstract}

Keywords: Cranial suture closure, Endocranial, Ectocranial.

\section{Introduction}

Recently, the number of unidentified bodies has increased globally, especially following the occurrence of acts of terrorism or natural disasters. Also what adds to this number is the increase in floating population in cities. In such a scenario, it is necessary to establish identity of large number of cadavers. Estimation of age at death by the aid of cranial suture closure could serve as a fundamental tool for this purpose.

The skull comprises of two parts viz. calvaria \& face. The bones of skull are separated by sutures, which in a sense are analogues of epiphysio-diaphysial planes in which there are loci of growth and they have a sequence and timing of union. ${ }^{1}$ The word suture is derived from Latin sutura, ${ }^{2}$ which means seam like or series of stitches.

Only handful of studies has been conducted on age of cranial suture closure in India, and data on heterogeneous population of Bangalore region is virtually non-existent.

Therefore this study will aid in determining the chronology and pattern of union of sagittal, coronal \& lambdoid sutures of the skull both endo and ectocranially in females.

\section{Material and Methods}

This study included medico legal cases subjected for autopsy at the Department of Forensic Medicine, MS Ramaiah Medical College, Bangalore from Nov2012 to Apr-2014, between the age group of 20 to 80 years. The study was conducted on 50 cases with validated age proof of females in the age group of 20 to 80 years.

The calvaria was removed by craniotome taking care that the transverse cut passes well below the lambda. The calvarium was cleaned of soft tissues and dried on both sides. The sagittal suture was divided into four equal segments from bregma to lambda: $\mathrm{S} 1, \mathrm{~S} 2$, S3, S4; starting from the sagittal suture each half of the coronal suture was divided into three equal parts CR1, CR2, CR3 on the right side and CL1, CL2, CL3 on the left side. Similarly, each half of the lambdoid suture was divided into three equal parts on the right side LR1, LR2, LR3 and LL1, LL2, LL3 on the left side.

All suture sections were studied using Acsadi and Nemeskeri scoring method which is as follows. ${ }^{3}$

$0=$ Open. There is still little space left between edges of adjoining bones.

1 = Incipient closure. Clearly visible as a continuous often zig zagging line.

2 = Closure in process. Line thinner, less zigzags, interrupted by complete closure.

3 = Advanced closure. Only pits indicate where the suture is located

4 = Closed. Even location cannot be recognized.

Mean sutural closure stages was calculated for the three main sutures and correlated with known age and statistically analysed. Spearman rank correlation coefficient was used for establishing statistical correlation between ecto and endo cranial sutures and the age group. SPSS version 20 was used for analyzing the data.

$\mathrm{P}<0.05$ was considered statistically significant.

\section{Results}

50 cases between the age group of 20-80 years fulfilling the inclusion criterion were taken up for the study. The cases included were divided into age group intervals of 10 years.

Of the total no of cases, in the age group of 20-29 years, there were 16 females (32\%). 10 females (20\%) were in the age group of 30-39 years. In 40-49 years 
age group there were 7 females (14\%). Age group of 50-59 years included 11 females (22\%). In 60-69 years age group there were 6 females (12\%). In 70-79 years age group and 80 and above there were 0 female $(0.0 \%)$.

\section{Table 1: Age wise sex distribution}

\section{Sagittal Suture}

Closure of ectocranial and endocranial sagittal suture was found to be age related. However complete ectocranial sagittal suture closure was observed in none

\begin{tabular}{|l|c|}
\hline $\begin{array}{c}\text { Age groups } \\
\text { (in years) }\end{array}$ & Female (\%) \\
\hline $20-29$ & $16(32)$ \\
\hline $30-39$ & $10(20)$ \\
\hline $40-49$ & $07(14)$ \\
\hline $50-59$ & $11(22)$ \\
\hline $60-69$ & $06(12)$ \\
\hline $70-79$ & $00(0.0)$ \\
\hline 80 and above & $00(0.0)$ \\
\hline Total & $50(100)$ \\
\hline
\end{tabular}

Table 2: Closure pattern of Sagittal Suture both ecto and endo-cranially

\begin{tabular}{|c|c|c|c|c|c|}
\hline \multirow{3}{*}{$\begin{array}{l}\text { Age Group } \\
\text { (in years) }\end{array}$} & \multirow{3}{*}{$\begin{array}{l}\text { No. of cases } \\
\text { (N) }\end{array}$} & \multicolumn{4}{|c|}{ Mean of Sagittal Suture Closure Stage } \\
\hline & & \multicolumn{2}{|c|}{$\begin{array}{l}\text { Ectocranial } \\
(\text { Ec-S })\end{array}$} & \multicolumn{2}{|c|}{$\begin{array}{c}\text { Endocranial } \\
(\text { En-S })\end{array}$} \\
\hline & & Mean & $\begin{array}{c}\text { Std. } \\
\text { deviation }\end{array}$ & Mean & Std. deviation \\
\hline $20-29$ & 16 & 0.607 & 0.57 & 0.892 & 0.88 \\
\hline $30-39$ & 10 & 1.31 & 0.23 & 1.875 & 0.25 \\
\hline $40-49$ & 07 & 1.75 & 0.35 & 2.62 & 0.53 \\
\hline $50-59$ & 11 & 2.12 & 0.25 & 3.01 & 0.69 \\
\hline $60-69$ & 06 & 2.12 & 0.17 & 3.37 & 0.17 \\
\hline $\begin{array}{c}70-79 \\
\end{array}$ & 0 & -- & $\mathrm{X}$ & -- & $\mathrm{X}$ \\
\hline $\begin{array}{l}80 \text { and } \\
\text { Above }\end{array}$ & 0 & -- & $\mathrm{X}$ & -- & $\mathrm{X}$ \\
\hline \multicolumn{2}{|c|}{ P-value } & \multicolumn{2}{|c|}{$\begin{array}{c}<0.001 \\
\text { Statistically significant }\end{array}$} & \multicolumn{2}{|c|}{$\begin{array}{c}<0.001 \\
\text { Statistically significant }\end{array}$} \\
\hline
\end{tabular}

Chart 1: Closure pattern of ecto and endo-cranial sagittal suture

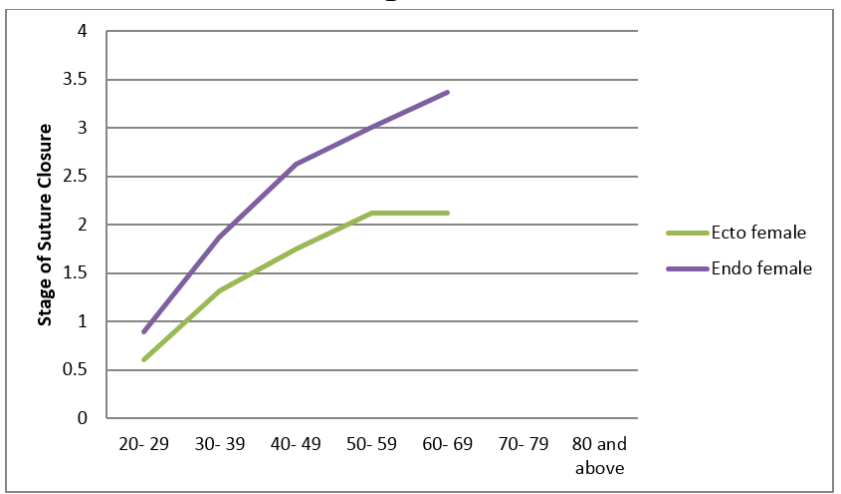

\section{Coronal Suture}

Closure of ectocranial and endocranial coronal suture was found to be age related. However complete coronal suture closure was observed in none of the age groups. Endocranially coronal sutures fused progressively from 20-29 years to 30-39 years of the age groups (lapsed union). Endocranially near complete closure of sagittal suture was seen at 50-59 years age group and above (Table $2 \&$ Chart 1). 
Table 3: Closure pattern of right and left coronal Suture both ecto and endo-cranially

\begin{tabular}{|c|c|c|c|c|c|c|c|c|c|}
\hline \multirow{4}{*}{$\begin{array}{c}\text { Age } \\
\text { Group } \\
\text { (in years) }\end{array}$} & \multirow{4}{*}{$\begin{array}{l}\text { No. of } \\
\text { cases } \\
(\mathrm{N})\end{array}$} & \multicolumn{8}{|c|}{ Mean of Coronal Suture Closure Stage } \\
\hline & & \multicolumn{4}{|c|}{ Ectocranial } & \multicolumn{4}{|c|}{ Endocranial } \\
\hline & & \multicolumn{2}{|c|}{ Ec-CR } & \multicolumn{2}{|c|}{ Ec-CL } & \multicolumn{2}{|c|}{ En-CR } & \multicolumn{2}{|c|}{ En-CL } \\
\hline & & Mean & SD & Mean & SD & Mean & SD & Mean & SD \\
\hline $20-29$ & 16 & 0.76 & 0.53 & 0.76 & 0.53 & 1.09 & 1.00 & 1.09 & 1.00 \\
\hline $30-39$ & 10 & 1.49 & 0.50 & 1.49 & 0.50 & 2.08 & 1.00 & 2.08 & 1.00 \\
\hline $40-49$ & 07 & 2 & 0.00 & 2 & 0.00 & 3.66 & 1.57 & 3.66 & 1.57 \\
\hline $50-59$ & 11 & 2.24 & 0.57 & 2.24 & 0.57 & 3.25 & 0.00 & 3.25 & 0.00 \\
\hline $60-69$ & 06 & 2.16 & 0.00 & 2.16 & 0.00 & 4 & 0.00 & 4 & 0.00 \\
\hline $70-79$ & 0 & -- & $\mathrm{x}$ & -- & $\mathrm{X}$ & -- & $\mathrm{x}$ & -- & $X$ \\
\hline $\begin{array}{l}80 \text { and } \\
\text { Above }\end{array}$ & 0 & -- & $\mathrm{X}$ & -- & X & -- & $\mathrm{X}$ & -- & X \\
\hline \multicolumn{2}{|c|}{$\mathrm{P}$-value } & \multicolumn{2}{|c|}{$\begin{array}{c}<0.001 \\
\text { Statistically } \\
\text { significant }\end{array}$} & \multicolumn{2}{|c|}{$\begin{array}{c}<0.001 \\
\text { Statistically } \\
\text { significant }\end{array}$} & \multicolumn{2}{|c|}{$\begin{array}{c}<0.001 \\
\text { Statistically } \\
\text { significant }\end{array}$} & \multicolumn{2}{|c|}{$\begin{array}{c}<0.001 \\
\text { Statistically } \\
\text { significant }\end{array}$} \\
\hline
\end{tabular}

Chart 2: Closure pattern of right and left coronal sutures both ecto and endo-cranially

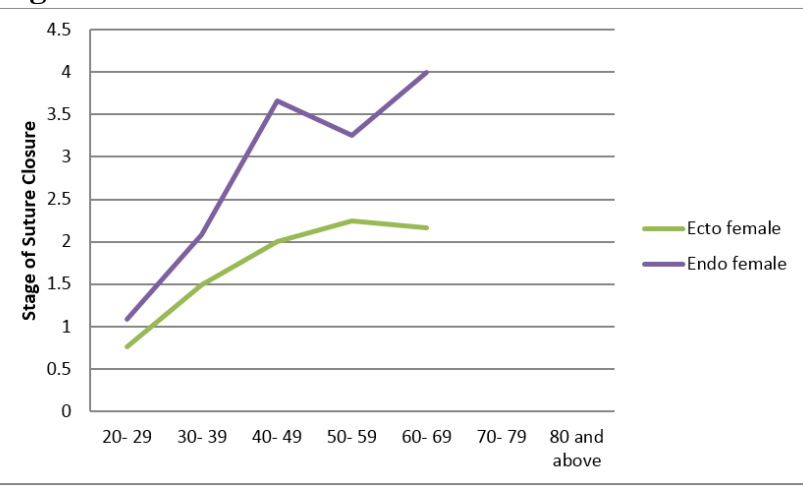

Lambdoid Suture: Closure of ectocranial and endocranial lambdoid suture was found to be age related. However ectocranially complete lambdoid suture closure was not observed in any of the age groups resulting in lapsed union.

Endocranially lambdoid sutures closure was seen in the age groups of 20-29 years, 30-39 years and 50-59 years. No complete closure was seen till 60-69 years age group.

I-Comparing right lambdoid with left lambdoid no difference in fusion pattern was found between them. (Table 4 - Chart 3).

Table 4: Closure pattern of right and left lambdoid suture both ecto and endo-cranially

\begin{tabular}{|c|c|c|c|c|c|c|c|c|c|}
\hline \multirow{4}{*}{$\begin{array}{c}\text { Age Group } \\
\text { (in years) }\end{array}$} & \multirow{4}{*}{$\begin{array}{l}\text { No. of } \\
\text { cases } \\
(\mathrm{N})\end{array}$} & \multicolumn{8}{|c|}{ Mean of Lambdoid Suture Closure Stage in females } \\
\hline & & \multicolumn{4}{|c|}{ Ectocranial } & \multicolumn{4}{|c|}{ Endocranial } \\
\hline & & \multicolumn{2}{|c|}{ Ec-LR } & \multicolumn{2}{|c|}{ Ec-LL } & \multicolumn{2}{|c|}{ En-LR } & \multicolumn{2}{|c|}{ En-LL } \\
\hline & & Mean & SD & Mean & SD & Mean & SD & Mean & SD \\
\hline $20-29$ & 16 & 0.57 & 0.53 & 0.57 & 0.53 & 0.86 & 0.90 & 0.86 & 0.90 \\
\hline $30-39$ & 10 & 1.25 & 0.50 & 1.25 & 0.50 & 1.75 & 0.95 & 1.75 & 0.95 \\
\hline $40-49$ & 07 & 2.33 & 0.57 & 2.33 & 0.57 & 3.67 & 0.57 & 3.67 & 0.57 \\
\hline $50-59$ & 11 & 1.67 & 0.57 & 1.67 & 0.57 & 2.33 & 0.57 & 2.33 & 0.57 \\
\hline $60-69$ & 06 & 2.00 & 0.00 & 2.00 & 0.00 & 3.00 & 0.00 & 3.00 & 0.00 \\
\hline $70-79$ & 0 & -- & $\mathrm{x}$ & -- & $\mathrm{X}$ & -- & $\mathrm{x}$ & -- & $\mathrm{X}$ \\
\hline $\begin{array}{l}80 \text { and } \\
\text { Above }\end{array}$ & 0 & -- & $\mathrm{x}$ & -- & $\mathrm{X}$ & -- & $\mathrm{x}$ & -- & $\mathrm{X}$ \\
\hline \multicolumn{2}{|c|}{ P-value } & \multicolumn{2}{|c|}{$\begin{array}{c}=0.002 \\
\text { Statistically } \\
\text { significant }\end{array}$} & \multicolumn{2}{|c|}{$\begin{array}{c}=0.002 \\
\text { Statistically } \\
\text { significant }\end{array}$} & \multicolumn{2}{|c|}{$\begin{array}{c}=0.002 \\
\text { Statistically } \\
\text { significant }\end{array}$} & \multicolumn{2}{|c|}{$\begin{array}{c}=0.002 \\
\text { Statistically } \\
\text { significant }\end{array}$} \\
\hline
\end{tabular}




\section{Chart 3: Closure pattern of right and left lambdoid Sutures both ecto and endo-cranially}

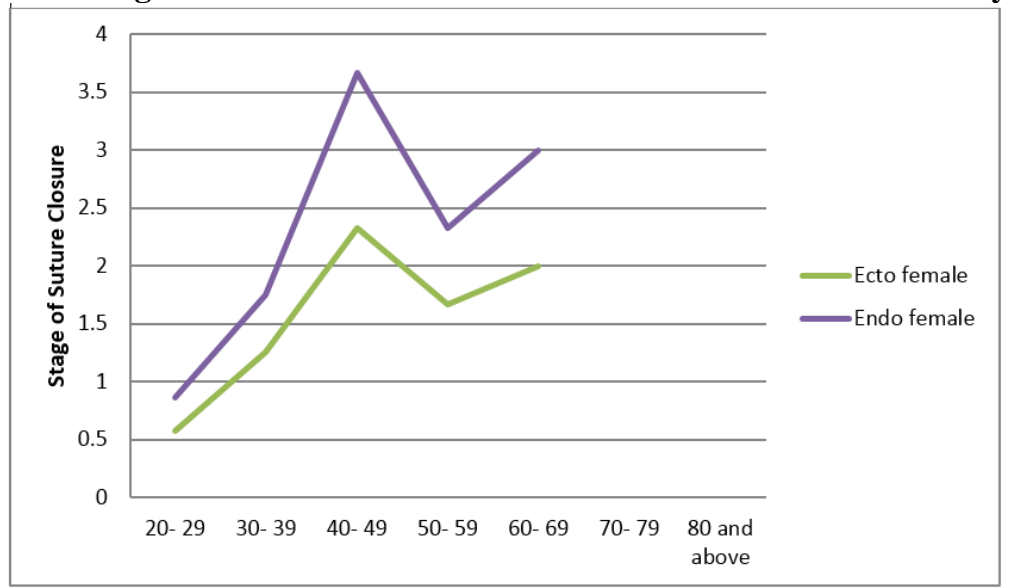

Correlation of suture closure pattern: Sagittal sutures, right and left coronal sutures and right and left lambdoid sutures were compared both ecto and endo cranially. (Table 5). For estimating the possible relation between suture closure and age at death spearman rank correlation coefficients were calculated. Ectocranial and endocranial suture closure were found to be correlating in the age group of 20-29 years and there after no correlation was seen in any age group.

Table 5: Correlation of ectocranial and endocranial suture closure with age

\begin{tabular}{|c|c|c|c|c|c|c|}
\hline Age Group & $\begin{array}{c}\text { No. of cases } \\
\text { Females }\end{array}$ & $\begin{array}{c}\text { Ec- SAG/ } \\
\text { En- SAG }\end{array}$ & $\begin{array}{c}\text { Ec- CR/ } \\
\text { En- CR }\end{array}$ & $\begin{array}{c}\text { Ec- CL/ } \\
\text { En- CL }\end{array}$ & $\begin{array}{c}\text { Ec- LR/ } \\
\text { En- LR }\end{array}$ & $\begin{array}{c}\text { Ec- LL/ } \\
\text { En- LL }\end{array}$ \\
\hline $20-29$ & \multirow{2}{*}{16} & $.971^{* *}$ & $.935^{* *}$ & $.935^{* *}$ & $.917^{* *}$ & $.917^{* *}$ \\
\cline { 3 - 7 } & & .004 & .002 & .002 & .004 & .004 \\
\hline \multirow{2}{*}{$30-39$} & \multirow{2}{*}{10} & $\mathrm{Xxx}$ & .333 & .333 & .816 & .816 \\
\cline { 3 - 7 } & & $\mathrm{xxx}$ & .667 & .667 & .184 & .184 \\
\hline \multirow{2}{*}{$40-49$} & \multirow{2}{*}{07} & $\mathrm{Xxx}$ & $\mathrm{xxx}$ & $\mathrm{Xxx}$ & .500 & .500 \\
\cline { 3 - 7 } & & $\mathrm{xxx}$ & $\mathrm{xxx}$ & $\mathrm{Xxx}$ & .667 & .667 \\
\hline \multirow{2}{*}{$50-59$} & \multirow{2}{*}{$60-69$} & .500 & $\mathrm{xxx}$ & $\mathrm{Xxx}$ & .500 & .500 \\
\cline { 3 - 7 } & \multirow{2}{*}{06} & .667 & $\mathrm{Xxx}$ & $\mathrm{Xxx}$ & .667 & .667 \\
\hline $70-79$ & & $\mathrm{Xxx}$ & $\mathrm{xxx}$ & $\mathrm{Xxx}$ & $\mathrm{Xxx}$ & $\mathrm{Xxx}$ \\
\hline 80 & -- & -- & -- & -- & -- \\
\hline 80 above & 0 & -- & -- & -- & -- & -- \\
\hline
\end{tabular}

* Correlation is significant at the 0.05 level (2-tailed).

** Correlation is significant at the 0.01 level (2-tailed).

In each age group upper row indicates the correlation coefficient and the row below indicates the p-value.

\section{Discussion}

Closure of ectocranial and endocranial sagittal, coronal and lambdoid suture was found to be age related. Ectocranial sagittal sutures complete closure was observed in none of the age groups which is similar to the observations made by Shetty U and Kumar et al. ${ }^{5}$

Endocranially near complete closure of sagittal suture was seen at 50-59 years age group and above contrarily William $\mathrm{F}$ et el in their study found this by 46-50 years. ${ }^{10}$

Ectocranially complete coronal suture closure was observed in none of the age groups. Endocranially coronal sutures fused progressively and complete closure was seen in 60-69 years age group. Right coronal and left coronal sutures showed no difference in fusion pattern between them.

Ectocranially complete lambdoid suture closure was not observed upto the age group 60-69 years. Endocranially lambdoid sutures closed progressively from the age groups of 20-29 years, 30-39 years and 50-59 years. Similar results were observed in study by Ullasa Shetty, ${ }^{5}$ Kumar et al. ${ }^{9}$

Right lambdoid and left lambdoid showed no difference in fusion pattern between them. Shetty U, and William $\mathrm{F}$ et al too found no significant difference in closure pattern of lambdoid suture when right side compared with left. ${ }^{5,10}$

Statistically significant correlation was found between ectocranial and endocranial suture closure in the age group of 20-29 years and there after no correlation was seen in any age group and suture 
closure became independent thereafter. In the study by Shetty $U$ no correlation was seen above the age of 40 years.

\section{Conclusion}

In this study we analysed the closure pattern of sagittal suture, left and right coronal suture and left and right lambdoid suture between the ages of 20 years to 80 years. We also analysed and compared the suture closure pattern ectocranially and endocranially.

Ectocranially suture closure was very erratic which makes its use as an indicator of age less reliable. Lapsed union of ectocranial sutures even at the age of 69 years adds to their low reliability. However progression of endocranial suture closure pattern was found to be age related and may be used as an indicator of age in conjunction with other tools of age estimation.

There were no study samples in the age group of 70-79 years and 80 years and above, hence progression of suture closure pattern could not be analysed in females of higher age groups. In future studies, age distribution of 10 years interval needs to be reduced to 5 years interval for the purpose of more precision in estimating age at death.

\section{References}

1. Meindl R.S, Lovejoy C.O, Ectocranial suture closure: a revised method for the determination of skeletal age at death based on the lateral anterior sutures, 1985 Sep, $A m$ J Phys Anthropol 68(1):57-66.

2. Ritz-Timme, S., Cattaneo, C., Collins, M. J., et al. Age estimation: the state of the art in relation to the specific demand of forensic practice. Int J Legal Med 2000;113:129-136.

3. Acsadi G, Nemeskeri J. History of human life span and mortality. Akademiai Kiado 1970;346.

4. Krogman WM, Iscan MY. Skeletal age: cranium. In: The Human skeleton in Forensic Medicine. Charles C Thomas Publishers 1986;2nd ed:103-32.

5. Shetty, U. Macroscopic study of cranial suture closure at autopsy for estimation of age (thesis submitted to the University of Delhi, 2008, for MD in Forensic Medicine). Anil Aggrawal's Internet J Forensic Med Toxicol 2009;10(2).

6. Saukko. P and Knight Bernard, Knights Forensic Pathology, 3rd ed, Arnold London 2004;120.

7. Mukherjee J. B. Identification. In: Textbook of Forensic Medicine and Toxicology, 4th edn, Academic publishers 2011;141-42.

8. T.W. Todd, D.W.Lyon jr. Endocranial suture closure. Its progress and age relationship part1. Adult males of white stock. Am J Phys Anthropol 1924;7:325-84.

9. Vijay Kumar AG, Agarwal SS, Bastia BK, Shivaramu MG, Honnungar RS (2012) Fusion of Skull Vault Sutures in Relation to Age-A Cross Sectional Postmortem Study Done in 3rd, 4th \& 5th Decades of Life. J Forensic Res $3: 173$.

10. William. F, Gupta. S, Jaiswal. P, Chand. A. E, Saraswat. P. K. Morphological study of vault suture \& its correlation with age in central rajasthan, Natl J Med Res 2014;4(1):19-22.
Abbreviations: Ec - Ectocranial, En - Endocranial, S Sagittal, CR- Coronal Right, CL - Coronal Left, LR Lambdoid Right, LL - Lambdoid Left. 